\author{
석묵 (Campylaephora hypnaeoides)의 생장과 \\ 성숙에 대한 야외 및 배양 연구 \\ 유현일·김지환 ${ }^{1}$ 최한길* \\ 원광대학교 생명과학부·기초자연과학연구소, ${ }^{1}$ 전라남도 해양수산과학원 해남지소
}

\title{
Field and Culture Studies on the Growth and Reproduction of Campylaephora hypnaeoides
}

\author{
Hyun Il Yoo, Ji Hwan Kim ${ }^{1}$ and Han Gil Choi* \\ Faculty of Biological Science and Institute of Basic Sciences, \\ Wonkwang University, Iksan 570-749, Korea \\ ${ }^{1}$ Jeollanam-do Provincial Government Ocean \& Fisheries Science Institute, \\ Haenam Branch, Haenam 536-812, Korea
}

The phenology of Campylaephora hypnaeoides J. Agardh and optimal conditions for carpospore release, growth and reproduction were examined in the field and in the laboratory from January to December 2007. In the field population of $C$. hypnaeoides, approximately $50 \%$ of the plants were vegetative during the study period. Additionally, the percentages of carposporophytes and tetrasporophytes were maximal in April (37\%) and June $(57 \%)$, respectively. Maximum growth in plant length, dry weight, and hook number coincided with the tetrasporophyte reproductive peak in the field. In culture, carpospore release, sporeling growth and reproduction were affected by environmental factors such as daylength, temperature, and salinity. The liberation of carpospores was maximum under continuous light and at a combination of $15^{\circ} \mathrm{C}$ and $10 \mu \mathrm{mol}$ photons $\mathrm{m}^{-2} \mathrm{~s}^{-1}$. Maximum growth of tetrasporophyte sporelings occurred at a combination of $20 \mu \mathrm{mol}$ photons $\mathrm{m}^{-2} \mathrm{~s}^{-1}$ of constant light and $25^{\circ} \mathrm{C}$. However, the growth of gametophyte sporelings was maximal under $40 \mu \mathrm{mol}$ photons $\mathrm{m}^{-2} \mathrm{~s}^{-1}$ of constant light and in a combination of $20^{\circ} \mathrm{C}$ and $35 \mathrm{psu}$. The tetrasporophyte sporelings were grew faster than gametophytes, indicating that gametophyte- and tetrasporophyte-sporelings have different physiological responses to irradiance and temperature. Tetrasporangial branches and cystocarps of $C$. hypnaeoides were produced from carpospores and tetraspores within 1 month, and they were stimulated at high temperature and irradiance levels. In conclusion, $C$. hypnaeoides should be seeded using carpospores during early winter (November-December) because cystocarps are easily identified by fishermen, and tetrasporophytes grow faster than gametophytes.

Key words: Campylaephora hypnaeoides, Growth, Reproduction, Spore release

\section{서 론}

홍조류 석묵 (Campylaephora hypnaeoides J. Agardh)은 비단 풀목 (目) 비단풀과 (科)에 속하는 사상형 해조류로 차상분지 하며 정단부에 있는 낫 모양의 갈고리로 조간대 하부나 조하대 에 서식하는 다른 해조류, 특히 모자반류에 부착하여 서식하는 착생해조류이다 (Kang, 1968; Yoo et al., 2010). 또한 석묵은 일본과 우리나라에 분포하는 고유종으로 (Kang, 1968; Boo, 1991), 한천의 원료, 식용, 식품첨가물로 다양하게 활용되고 있다 (Kirihara et al., 1990; Do et al., 1997). 우리나라에서는 석묵에 대한 분류학적 연구만이 수행되었으며 (Boo, 1991), 일본에서는 생활사, 배우체와 포자체의 실내 배양 (Notoya, 1979)과 해면양식용 씨줄생산 (seedling production)과 야외 양 성에 대한 연구가 수행되었다 (Kirihara et al., 1990).

해조류에 대한 양식기술 개발은 먼저 대상해조류 야외개 체군의 계절적 생장 및 성숙시기를 파악한 후, 종묘확보를

*Corresponding author: hgchoi@wku.ac.kr
위한 최적 포자방출조건과 야외양성의 세대선택 (generation selection)을 위한 배우체와 포자체의 최적생장조건 파악 및 생장비교를 거쳐서 해면양식의 절차 (protocol)를 확립하는 것이다 (Destombe et al., 1993; González and Meneses, 1996; Choi et al., 2006). 해조류의 포자방출은 온도와 삼투충격, 달 과 조석리듬, 조도 등 다양한 환경요인의 영향을 받는 것으로 잘 알려져 있으며 (Friedlander and Dawes, 1984; Santelices 1990; Guzmán-Urióstegui and Robledo, 1999), 대상종에 따라 포자방출을 유도하는 조건이 다른 것으로 확인되었다 (Matsui, 1969; Subba Rangaiah, 1985; Fonck et al., 1998). 현재 까지 석묵 야외개체군의 계절적 생장 및 성숙, 그리고 포자방 출에 대한 연구가 전혀 수행되지 않은 상태이다. 생장의 경우, Notoya (1979)는 석묵 포자체와 배우체의 생장을 위한최적수 온은 $20^{\circ} \mathrm{C}$ 로 동일하지만, 조도는 배우체 $(160 \mu \mathrm{mol}$ photons $\left.\mathrm{m}^{-2} \mathrm{~s}^{-1}\right)$ 와 사분포자체 $\left(40 \mu \mathrm{mol}\right.$ photons $\left.\mathrm{m}^{-2} \mathrm{~s}^{-1}\right)$ 가 다르고 배우 체에 비해 사분포자체의 생장이 빠른 것을 보고하였다. 하지

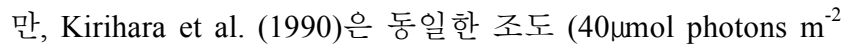


$\mathrm{s}^{-1}$ )에서 석묵의 사분포자체와 자성배우체가 각기 $15^{\circ} \mathrm{C}$ 와 2 $5^{\circ} \mathrm{C}$ 에서 최대생장을 보인다고 하여, 개체군과 세대 (배우체, 포 자체)별로 수온과 조도에 대한 생장반응이 다름을 확인하였다.

따라서, 본 연구는 한국산 석묵 야외개체군의 최적 생장 및 성숙시기를 확인하고 최대 포자방출법과 배우체와 사분포 자체 배아의 최적생장조건을 탐색하여, 향후 석묵의 대량양식 을 위한 종묘확보 및 야외양성의 기본적인 정보를 제공하기 위하여 수행되었다.

\section{재료 및 방법}

야외 개체군의 생물계절학

전남 완도군 보길도 $\left(34^{\circ} 08^{\prime} \mathrm{N}, 126^{\circ} 33^{\prime} \mathrm{E}\right)$ 의 양식 톳에 착생한 석묵을 2007년 1월부터 12월까지 월별로 무작위로 채집하여 플라스틱 봉투에 넣어 실험실로 운반하였다. 2007년 3월에는 기상여건이 좋지 않아 샘플채집이 불가능하였으며 7월부터는 양식 톳에서 석묵이 사라졌다. 운반된 석묵은 여과해수 ( $\varnothing$ $0.45 \mu \mathrm{m}$ )로 세척하여 부착 동.식물을 제거한 후 무작위로 30 개 체를 선택하여 광학현미경 하에서 생식상태를 확인하였다. 또한, 유성생식과 더불어 영양번식을 하는 석묵의 개체별 갈고 리 수와 생장의 관계를 확인하기 위하여 월별 갈고리수와 길이 를 측정하고 $60^{\circ} \mathrm{C}$ 로 세팅된 건조기에서 7일간 건조한 후 건중 량을 전자저울로 $0.01 \mathrm{mg}$ 까지 측정하였다. 연구 해역의 수온 과 염분은 한국해양자료센터 (http://kodc.nfrdi.re.kr)의 완도군 청산도 자료를 사용하였다 (NFRDI, 2007).

\section{과포자 방출 유도}

홍조류 석묵의 생활사 중에서 빠른 생장을 보여 Kirihara et al. (1990)에 의해 양식대상으로 언급된 사분포자체로 생장 하는 과포자가 최대로 방출되는 조건을 탐색하기 위해, 보길도 의 양식 톳에 착생한 낭과 (cystocarp)를 가진 과포자체를 2007 년 12월에 채집하여 현장에서 해수와 함께 플라스틱병에 담아 실험실로 운반하였다. 실험실에서 여과 및 멸균해수로 성숙한 과포자체를 수회 세척하여 부착규조류와 착생동물을 제거하 였다. 석묵은 낭과 크기에 따라 성숙차이를 보인다는 가정하에 유사한 크기의 낭과를 실험에 사용하였다. 멸균해수 $10 \mathrm{~mL}$ 이 담긴 디쉬 (6 well plate)에 낭과를 10 개씩 넣고 다양한 일장 $(0,8,12,16,24 \mathrm{~h})$ 에서 포자방출을 유도하였으며, 이 때 온도 $\left(15^{\circ} \mathrm{C}\right)$ 와 조도 $\left(40 \mu \mathrm{mol}\right.$ photons $\left.\mathrm{m}^{-2} \mathrm{~s}^{-1}\right)$ 는 일정하게 유지하였 다. 또한, 석묵의 포자 방출에 대한 온도 $\left(10,15,20,25^{\circ} \mathrm{C}\right)$ 와 조도 $\left(10,20,40 \mu \mathrm{mol}\right.$ photons $\left.\mathrm{m}^{-2} \mathrm{~s}^{-1}\right)$ 의 영향을 동일한 일장 $(16 \mathrm{~h})$ 에서 확인하였다. 각 실험구에서 방출된 석묵 포자의 수는 24시간 간격으로 배양용기를 교환하면서 3회 (배양시간 총 72 시간)에 걸쳐 현미경하에서 계수하였고 조건별로 3 개의 반복구를 두었다.

\section{배양 조건별 생장과 성숙}

전남 완도군 보길도에서 양식 톳에 부착한 석묵의 과포자체 는 2006년 12월에, 사분포자체는 2007년 6월에 각각 채집하여 현장에서 해수와 함께 샘플병에 담아 실험실로 운반하였다. 샘플은 멸균해수로 수회 세척한 후 낭과와 사분포자탁을 조체
에서 절단하여 슬라이드글라스 조각 $(20 \times 20 \mathrm{~mm})$ 과 $100 \mathrm{~mL}$ 의 $\mathrm{PES}$ 배지 (Provasoli, 1968)가 담긴 비이커에 넣어 $15^{\circ} \mathrm{C}$ 와 20 $\mu \mathrm{mol}$ photons $\mathrm{m}^{-2} \mathrm{~s}^{-1}$ 및 $16 \mathrm{~h}$ 의 일장 (광주기: $16: 8 \mathrm{~h} \mathrm{~L}: \mathrm{D}-$ Light:Dark)으로 세팅된 배양기에서 48시간 포자방출을 유도 하였다. 포자 방출이 확인된 후 석묵 조체를 비이커에서 제거 하고 포자가 슬라이드글라스 조각의 표면에 부착되도록 24시 간 방치하였다. 사분포자 혹은 과포자가 부착된 슬라이드글라 스 조각은 $30 \mathrm{~mL}$ 의 $\mathrm{PES}$ 배지가 들어있는 페트리디쉬에 옮겨 다양한 조도 $\left(0,20,40 \mu \mathrm{mol}\right.$ photons $\left.\mathrm{m}^{-2} \mathrm{~s}^{-1}\right) \times$ 일장 $(8,12$, $16,24 \mathrm{~h})$ 과 온도 $\left(10,15,20,25^{\circ} \mathrm{C}\right) \times$ 염분 $(15,25,35 \mathrm{psu})$ 에서 3 일 간격으로 배양액을 교환하면서 14 일간 배양하였다. 각 조건 별로 3 개의 반복구를 두었으며, 반복구별로 20 개의 배아를 무작 위로 선택하여 가근을 제외한 길이를 측정하였다. 석묵배아의 상대생장률 (PGR, relative growth rate)은 배양개시 $\left(T_{1}\right)$ 때의 포자 크기 $(50.47 \pm 0.22 \mu \mathrm{m}, \mathrm{n}=30)$ 와 배양 14 일 후 $\left(T_{2}\right)$ 의 배아 길이를 측정하여 계산하였다 (Rueness and Tananger, 1984).

$$
\mathrm{RGR}=\left(\ln P_{\mathrm{t} 2}-\ln P_{\mathrm{t} 1}\right) / T_{1}-T_{2}
$$

여기서 $P_{\mathrm{t} 1}$ 과 $P_{\mathrm{t} 2}$ 는 각각 $T_{1}$ 과 $T_{2}$ 시간의 배아의 길이를 의미 한다. 석묵 배아의 성숙 유·무는 길이측정을 마친 배아들을 조건별로 한 개의 비이커로 옮긴 후 생장실험과 동일한 조건에 서 배양하면서 현미경 하에서 확인하였다.

\section{통계분석}

모든 실험 데이터는 Levene의 등분산검정 (test of homogeneity of variances)을 실시하여 동질성을 확인한 후에 One-way 혹은 Two-way ANOVA로 유의차를 검정하였으며, 자료에 대한 유의차가 확인되면 Tukey's test로 사후검정을 실시하였다. 일장에 따른 포자방출은 One-way ANOVA로, 온 도-조도에 따른 포자 방출량은 Two-way ANOVA로 유의차를 확인하였다. 또한, 일장 - 조도가 배우체 및 사분포자체 배아 의 생장에 미치는 영향과 온도 - 염분이 배우체 배아의 생장 에 미치는 영향은 Two-way ANOVA로, 온도가 사분포자체 배아의 생장에 미치는 영향은 One-way ANOVA로 유의차를 검정하였다. 온도-염분의 생장 실험에서 사분포자체 배아의 상대생장률 자료는 데이터를 변환 (log transformation)하여 데 이터의 동질성을 확보하여 분석하였으며, 모든 자료분석은 STATISTICA version 7.0을 사용하여 수행되었다.

\section{결 과}

야외 개체군의 생장 및 성숙

완도군 보길도 양식 톳에서 석묵은 2006년 11월에 출현하였 으나, 성숙상태에 대한 연구는 2007년 1월에 개시하여 소멸되 기 이전인 6월까지 수행하였고 석묵은 11 월에 다시 출현하였 다 (Table 1). 석묵이 관찰된 시기의 완도 청산도 수온은 $10.52-16.56^{\circ} \mathrm{C}$ 로서 2 월에 최저였고 6 월에 최대였다. 수온이 $18.99-20.43^{\circ} \mathrm{C}$ 으로 상승한 7-10월에는 양식 톳에서 석묵이 발 견되지 않았다. 염분은 조사기간 동안 29.35-32.85 psu로서 9월 가장 낮았고 11월에 최대였다 (Table 1). 
Table 1. Reproductive phenology of Campylaephora hypnaeoides grown on the cultivation rope of Sargassum fusiformis at Wando from January to December 2007. Seawater temperature and salinity data were obtained from Korea oceanographic data center

\begin{tabular}{lcccccccccccc}
\hline Reproductive status & Jan. & Feb. & Mar. & Apr. & May & June & July & Aug. & Sep. & Oct. & Nov. & Dec. \\
\hline Vegetative & +++ & +++ & $*$ & ++ & +++ & ++ & - & - & - & - & +++ & +++ \\
Tetrasporic & - & - & $*$ & + & ++ & +++ & - & - & - & - & + & + \\
Spermatangial & + & + & $*$ & + & + & + & - & - & - & - & - & - \\
Cystocarpic & ++ & ++ & $*$ & ++ & + & + & - & - & - & - & ++ \\
\hline Temperature $\left({ }^{\circ} \mathrm{C}\right)$ & 11.23 & 10.52 & 10.75 & 12.09 & 14.57 & 16.56 & 18.99 & 21.65 & 24.11 & 20.43 & 14.83 & 12.16 \\
Salinity (psu) & 30.38 & 30.72 & 32.25 & 31.79 & 31.84 & 32.72 & 32.22 & 30.46 & 29.35 & 32.00 & 32.85 & 32.42 \\
\hline
\end{tabular}

Asterisks (*) present no sample collection. - , No observation. Proportion of each reproductive stage is represented as follows; +, 0-20\%; ++, 21-40\%, +++, 41-60\%.

양식 톳에 착생한 석묵개체군에서 영양체 비율은 2007년 1-2 월에 최대 (46.67-50.00\%)였고 이후 점차 감소하였다. 웅성에 배우체는 1-6월에 계속적으로 낮은 상태 ( $20 \%$ 이하)를 유지하 였고 낭과를 가진 자성배우체는 1-4월에 비교적 높은 비율을 보였으나 5월과 6 월에 급격하게 감소하였다. 반면, 사분포자 체는 수온이 상승하는 4월에 발견된 후 웅성체와 자성체가 사라지는 5-6월에 급격히 증가하였으며, 수온이 약 $19^{\circ} \mathrm{C}$ 에 이르는 7월에 석묵이 녹아내려 완전히 사라졌다. 하지만, 수온 이 $15^{\circ} \mathrm{C}$ 이하 $\left(14.48^{\circ} \mathrm{C}\right)$ 로 하강하는 11 월에 출현한 석묵의 영양 체 비율은 $63.33 \%$ 로 매우 높았고 12월 다소 감소하였다. 자성 체는 11 월 비교적 높은 비율을 보였으나 이후 급감하였으며, 웅성체는 생육기간 동안 관찰되지 않았다 (Table 1).

석묵의 체장은 9.28-13.96 cm로 1 월에 최소 $(9.28 \pm 2.02 \mathrm{~cm}$, $\mathrm{Mean} \pm \mathrm{SE}$ )였고 2월에 $10.37 \pm 3.05 \mathrm{~cm}$ 로 생장한 후 사분포자체 가 급격히 증가한 6월에 최대 체장 $(13.96 \pm 5.10 \mathrm{~cm})$ 을 보이고 7월에는 석묵이 녹아내리면서 사라졌다. 새로 설치된 톳 친승. 줄에서 석묵은 수온이 하강한 11월에 다시 발견되었으며, 체장
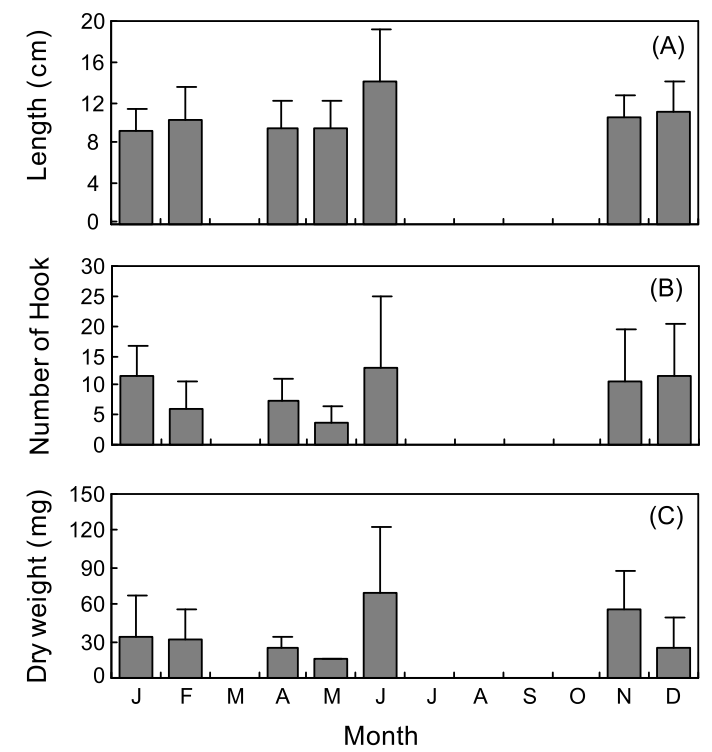

Fig. 1. Monthly variations of plant length (A), hook number (B) and dry weight (C) in Campylaephora hypnaeoides of Wando populations. Bars are standard errors $(\mathrm{n}=30$ plants).
은 $10.43 \pm 2.38 \mathrm{~cm}$ 였고, 점차 생장하여 12 월에는 $11.03 \pm 3.04$ $\mathrm{cm}$ 였다 (Fig. 1A) 석묵 조체의 갈고리수와 건중량의 월별 변화 는 매우 유사한 패턴을 보였다 (Fig. $1 \mathrm{~B}, \mathrm{C}$ ). 석묵 조체의 갈고리 수는 3.90-13.13개로서 1 월 $(11.63 \pm 4.78$ 개)에서 5월 $(3.90 \pm 2.64$ 개)까지 점차 감소하였으나, 6월에 급격히 증가하여 $13.13 \pm 11.66$ 개로 최대였다. 새로운 톳 친승줄이 설치된 후에 다시 출현한 석묵의 갈고리 수는 11 월에 $10.80 \pm 8.41$ 개, 12 월에 $11.37 \pm 8.80$ 개였다 (Fig. 1B). 석묵의 야외 개체군에서 각 조체 별 건중량은 15.20 - $68.29 \mathrm{mg}$ 로 갈고리수의 변화와 유사한 패 턴으로 1 월부터 지속적으로 감소하여 5월에 최소 $(15.20 \pm 1.08$ $\mathrm{mg}$ )를 나타낸 후 사분포자체가 급증하는 6월에 최대값 $(68.29 \pm 54.57 \mathrm{mg})$ 을 보였고 7월에 조체가 사라졌다. 그리고 11 월의 조체별 건중량은 $56.04 \pm 31.24 \mathrm{mg}$ 이었으며, 12 월에는 약간 감소하였다 (Fig. 1C).

과포자 방출유도

\section{일장의 영향}

석묵의 과포자의 일별 방출된 평균 포자수는 암조건에서 최소 $(45.11 \pm 0.87$ 개/day, Mean $\pm \mathrm{SE})$ 였고, 일장과 함께 증가하 여 $8 \mathrm{~h}$ 에서 $72.22 \pm 6.93$ 개/day, $12 \mathrm{~h}$ 에서 $77.11 \pm 4.62$ 개/day, $16 \mathrm{~h}$ 에서 $79.22 \pm 6.74$ 개/day였고, 연속광 $(24 \mathrm{~h})$ 에서 최대 $(82.83 \pm$ 3.37 개/day)였다. 방출된 포자수는 암조건에서 현저하게 낮았 으나 $\left(F_{4,10}=8.78, P<0.01\right)$, 일장의 길이 $(8,12,16,24 \mathrm{~h})$ 에 따른 포자방출량은 유의차가 없는 것으로 확인되었다 (Tukey test).

\section{온도-조도의 영향}

석묵의 낭과는 다양한 온도 $\left(10,15,20,25^{\circ} \mathrm{C}\right)$-조도 $(10,20$, $40 \mu \mathrm{mol}$ photons $\mathrm{m}^{-2} \mathrm{~s}^{-1}$ )가 조합된 모든 실험구에서 과포자를 방출하였다 (Fig. 2). 온도별로 방출된 포자수는 3-66개/day로 서 $25^{\circ} \mathrm{C}$ 에서 최소였고 $15^{\circ} \mathrm{C}$ 에서 최대였으며, 포자방출의 최적 온도는 $15^{\circ} \mathrm{C}$ 와 $20^{\circ} \mathrm{C}$ 로 나타났다 $\left(F_{3,30}=48.54, P<0.01\right)$. 조도별 과포자 방출은 $40 \mu \mathrm{mol}$ photons $\mathrm{m}^{-2} \mathrm{~s}^{-1}$ 에서 38 개/day로 가장 많았고 $20 \mu \mathrm{mol}$ photons $\mathrm{m}^{-2} \mathrm{~s}^{-1}$ 에서 25 개로 최소를 보였다 $\left(F_{2,30}=3.70, P<0.01\right)$. 온도와 조도의 조합조건에서는 1-75개/ day의 포자가 방출되었으며 $15^{\circ} \mathrm{C}$ 의 $10 \mu \mathrm{mol}$ photons $\mathrm{m}^{-2} \mathrm{~s}^{-1}$ 에 서 최대였고, $25^{\circ} \mathrm{C}$ 의 $40 \mu \mathrm{mol}$ photons $\mathrm{m}^{-2} \mathrm{~s}^{-1}$ 에서 최소였다 (Fig. 2). 


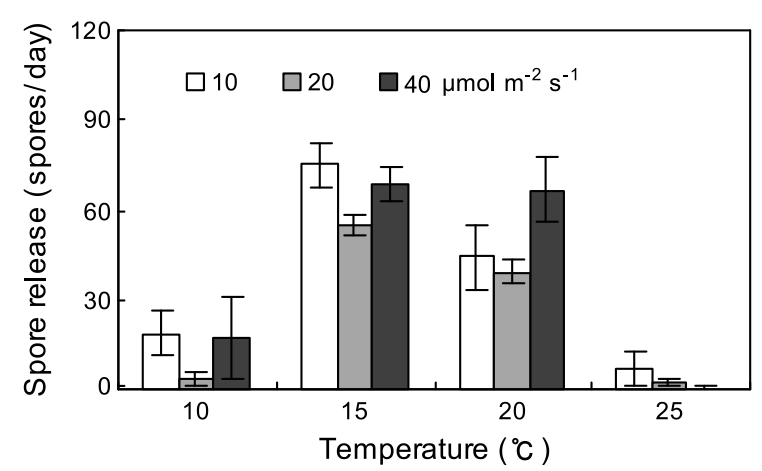

Fig. 2. Effects of temperature and irradiance on carpospore release of Campylaephora hypnaeoides under a daylength of $16 \mathrm{~h}$. Bars are standard errors ( $\mathrm{n}=3$ replicates).

배양조건별 석묵의 생장

일장-조도의 영향

석묵의 사분포자체 및 배우체 배아를 다양한 일장 $(8,12$, $16,24 \mathrm{~h})$ 과 조도 $\left(10,20,40 \mu \mathrm{mol}\right.$ photons $\left.\mathrm{m}^{-2} \mathrm{~s}^{-1}\right)$ 에서 14 일간 배양한 후 상대생장률을 비교하였다. 사분포자체 배아의 일장 별 상대생장률은 연속광 $(24 \mathrm{~h})$ 에서 최대 $\left(0.29 \mathrm{day}^{-1}\right.$, 길이 $2.23 \pm 0.22 \mathrm{~mm})$ 였으며 일장이 짧아질수록 감소하였다 $\left(F_{3,30}=\right.$ 65.28, P<0.01). 조도별 생장률은 0.20-0.24 $\mathrm{day}^{-1}$ 로 $20 \mu \mathrm{mol}$ photons $\mathrm{m}^{-2} \mathrm{~s}^{-1}$ 에서 최대였고 $10 \mu \mathrm{mol}$ photons $\mathrm{m}^{-2} \mathrm{~s}^{-1}$ 에서 가장 낮았다. 일장-조도에 따른 생장은 0.15-0.30 day ${ }^{-1}$ 로서 연속광 (24 h)의 $20 \mu \mathrm{mol}$ photons $\mathrm{m}^{-2} \mathrm{~s}^{-1}$ 에서 최대 (길이 $2.46 \pm 0.14 \mathrm{~mm}$ )였고 $8 \mathrm{~h}$ 의 10umol photons $\mathrm{m}^{-2} \mathrm{~s}^{-1}$ 에서 최소생장을 나타났다 $\left(F_{2,30}=31.34\right.$, $P<0.01)$. 사분포자체 배아의 최대생장은 장일조건 $(16-24 \mathrm{~h})$ 에서는 $20 \mu \mathrm{mol}$ photons $\mathrm{m}^{-2} \mathrm{~s}^{-1}$ 에서 그리고 단일조건 (8-12 h)에서는 $40 \mu$ mol photons $\mathrm{m}^{-2} \mathrm{~s}^{-1}$ 에서 일어났다 (Fig. 3A).

사분포자를 배양한 석묵 배우체 배아의 생장률은 일장별로 0.23-0.28 day ${ }^{-1}$ 였고, 포자체 배아와 마찬가지로 연속광 $(24 \mathrm{~h})$ 에서 최대 (길이 $2.04 \pm 0.11 \mathrm{~mm}$ )였고 일장이 짧을수록 생장도 감소하였다 $\left(F_{3,30}=17.70, P<0.01\right)$. 조도별 배우체 배아의 생장 은 $40 \mu \mathrm{mol}$ photons $\mathrm{m}^{-2} \mathrm{~s}^{-1}$ 에서 $0.27 \mathrm{day}^{-1}$ 로 최대였고 조도가 낮을수록 감소되었다 $\left(F_{2,30}=8.90, P<0.01\right)$. 일장-조도의 조합에 서 배우체 배아의 생장은 연속광 $(24 \mathrm{~h})$ 의 $40 \mu \mathrm{mol}$ photons $\mathrm{m}^{-2}$ $\mathrm{s}^{-1}$ 에서 $0.29 \mathrm{day}^{-1}$ 로 최대였고, 최소생장은 사분포자체 배아와 마찬가지로 $8 \mathrm{~h}$ 의 $10 \mu \mathrm{mol}$ photons $\mathrm{m}^{-2} \mathrm{~s}^{-1}$ 에서 일어났다. 배우체 배아는 일장에 상관없이 $40 \mu \mathrm{mol}$ photons $\mathrm{m}^{-2} \mathrm{~s}^{-1}$ 에서 최대생장 을 보였으며, 낮은 조도에서는 생장이 지연되었다. 또한, 연속 광 $(24 \mathrm{~h})$ 에서 생장률은 $0.28-0.29 \mathrm{day}^{-1}$ 로서 조도의 영향이 거 의 없었으나, 단일조건 $(8 \mathrm{~h})$ 에서 생장률은 0.21-0.26 day ${ }^{-1}$ 로서 조도에 따라 생장 차이를 보였다 (Fig. 3B).

\section{온도-염분의 영향}

석묵의 과포자에서 유래한 사분포자체 배아를 $10-25^{\circ} \mathrm{C}$ 에 서, 그리고 사분포자에서 생장한 배우체 배아를 $10-25^{\circ} \mathrm{C}$ 의 온도와 $15-35 \mathrm{psu}$ 의 염분농도에서 14 일간 배양하였다. 사분포 자체 배아의 온도별 생장은 $10^{\circ} \mathrm{C}$ 에서 최소 $\left(0.17 \mathrm{day}^{-1}\right.$, 길이
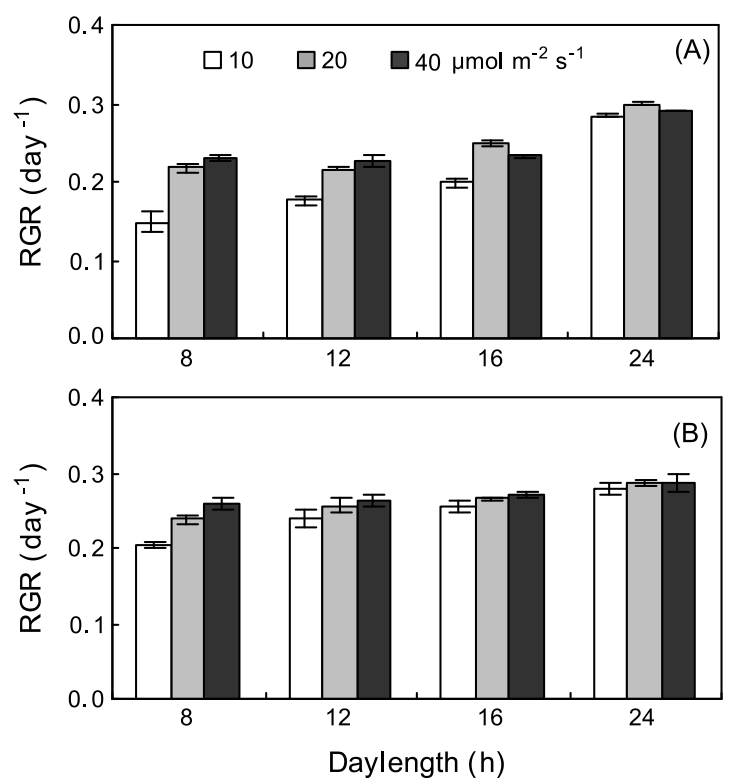

Fig. 3. The PGR of tetrasporophyte sporelings (A) and gametophyte sporelings (B) of Campylaephora hypnaeoides at four different daylength and three irradiance levels. Plants were cultured at $15^{\circ} \mathrm{C}$ for 14 days. Bars are standard errors $(n=3$ replicates $)$.

$0.47 \pm 0.01 \mathrm{~mm})$ 였고, $15^{\circ} \mathrm{C}$ 에서 $0.23 \mathrm{day}^{-1}(1.04 \pm 0.10 \mathrm{~mm})$, $20^{\circ} \mathrm{C}$ 에서 $0.27 \mathrm{day}^{-1}(1.75 \pm 0.16 \mathrm{~mm})$, 그리고 $25^{\circ} \mathrm{C}$ 에서 0.32 $\mathrm{day}^{-1}(3.02 \pm 0.04 \mathrm{~mm})$ 로 온도와 생장률은 비례하여 증가하는 패턴을 보였다 $\left(F_{3,8}=359.79, P<0.01\right)$. 석묵 사분포자에서 생장 한 배우체 배아의 온도별 생장률은 0.21-0.26 day ${ }^{-1}$ 로 고온에서 빠른 생장을 보였으며 저온에서 생장은 지연되었다 $\left(F_{3,30}=\right.$ $45.17, P<0.01)$. 염분 농도별 생장은 일반해수 농도인 $35 \mathrm{psu}$ 에 서 최대 생장률 $\left(0.27 \mathrm{day}^{-1}\right)$ 을 나타내었고, $15 \mathrm{psu}$ 에서 0.20 $\mathrm{day}^{-1}$ 로 가장 느린 생장을 보였다 $\left(F_{2,30}=189.91, P<0.01\right)$. 온 도-염분 농도에 따른 생장은 $20^{\circ} \mathrm{C}$ 의 $35 \mathrm{psu}$ 에서 최대 (길이 $2.15 \pm 0.11 \mathrm{~mm})$ 였으며 고온 $\left(25^{\circ} \mathrm{C}\right)$ 에서는 $35 \mathrm{psu}$ 에서 생장이 감소되었다 (Fig. 4).

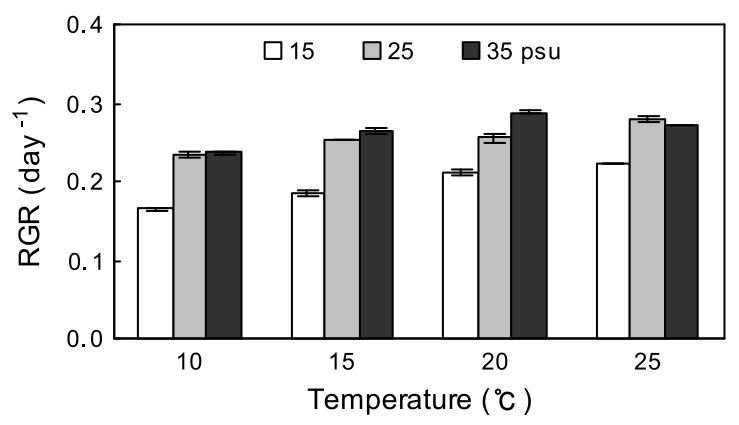

Fig. 4. The RGR of gametophyte sporelings of Campylaephora hypnaeoides at four different temperature and three salinity levels. Plants were cultured under a daylength of $16 \mathrm{~h}$ and $40 \mu \mathrm{mol}$ photons $\mathrm{m}^{-2} \mathrm{~s}^{-1}$ for 14 days. Bars are standard errors $(\mathrm{n}=3$ replicates $)$. 
Table 2. Tetrasporangial branch and cystocarp formation of Campylaephora hypnaeoides at different experimental conditions

\begin{tabular}{|c|c|c|}
\hline Experiments & Day from start & Initiation order \\
\hline $\begin{array}{l}\text { Tetrasporangial branch formation } \\
\text { Temperature exp. } \\
\quad \text { at } 20 \mu \mathrm{mol} \text { photons } \mathrm{m}^{-2} \mathrm{~s}^{-1} \text { and } 16 \mathrm{~h}\end{array}$ & $30-35$ & $25>20>15,10^{\circ} \mathrm{C} *$ \\
\hline $\begin{array}{l}\text { Daylength exp. } \\
\text { at } 15^{\circ} \mathrm{C} \text { and } 40 \mu \mathrm{mol} \text { photons } \mathrm{m}^{-2} \mathrm{~s}^{-1}\end{array}$ & $31-36$ & $24>16,12 *, 8 \mathrm{~h} *$ \\
\hline $\begin{array}{l}\text { Photon irradiance exp. } \\
\text { at } 15^{\circ} \mathrm{C} \text { and } 16 \mathrm{~h} \\
\text { at } 15^{\circ} \mathrm{C} \text { and } 24 \mathrm{~h}\end{array}$ & $\begin{array}{c}36 \\
31-32\end{array}$ & $\begin{array}{l}40=20,10 \mu \mathrm{mol} \text { photons } \mathrm{m}^{-2} \mathrm{~s}^{-1} * \\
40=20>10 \mu \mathrm{mol} \text { photons } \mathrm{m}^{-2} \mathrm{~s}^{-1} *\end{array}$ \\
\hline $\begin{array}{l}\text { Cystocarp formation } \\
\text { Temperature exp. } \\
\quad \text { at } 20 \mu \text { mol photons } \mathrm{m}^{-2} \mathrm{~s}^{-1} \text { and } 16 \mathrm{~h}\end{array}$ & $22-32$ & $25>20>15,10^{\circ} \mathrm{C} *$ \\
\hline $\begin{array}{l}\text { Daylength exp. } \\
\text { at } 15^{\circ} \mathrm{C} \text { and } 40 \mu \mathrm{mol} \text { photons } \mathrm{m}^{-2} \mathrm{~s}^{-1}\end{array}$ & $22-29$ & $24>16,12 *, 8 \mathrm{~h} *$ \\
\hline $\begin{array}{l}\text { Photon irradiance exp. } \\
\text { at } 15^{\circ} \mathrm{C} \text { and } 16 \mathrm{~h} \\
\text { at } 15^{\circ} \mathrm{C} \text { and } 24 \mathrm{~h}\end{array}$ & $\begin{array}{l}29 \\
22\end{array}$ & $\begin{array}{l}40=20,10 \mu \mathrm{mol} \text { photons } \mathrm{m}^{-2} \mathrm{~s}^{-1} * \\
40=20=10 \mu \mathrm{mol} \text { photons } \mathrm{m}^{-2} \mathrm{~s}^{-1} *\end{array}$ \\
\hline
\end{tabular}

*No Tetrasporangial branch and cystocarp.

배양조건별 석묵 성숙

사분포자탁 형성

석묵 과포자가 발아하여 생장한 사분포자체는 $15-25^{\circ} \mathrm{C}$ 에서 성숙되었으며, 사분포자탁은 $25^{\circ} \mathrm{C}$ 에서 배양 30 일 후에 최초로 관찰되었고 2 일 후에 사분포자가 방출되었다. 사분포자탁은 $15^{\circ} \mathrm{C}$ 에서 배양 35 일 후에 형성되었고 3 일 후인 38 일에 포자가 방출되었다. 하지만, $10^{\circ} \mathrm{C}$ 에서 배양한 사분포자체는 배양 45 일까지 사분포자탁이 형성되지 않았다 (Table 2).

일장 및 조도실험에서는 $16-24 \mathrm{~h}$ 의 장일 조건에서만 사분포 자탁이 형성되어 포자가 방출되었으며, 연속광 $(24 \mathrm{~h})$ 에서는 모든 실험조도 $\left(10,20,40 \mu \mathrm{mol}\right.$ photons $\left.\mathrm{m}^{-2} \mathrm{~s}^{-1}\right)$ 에서 배양 개시 31-32일 후에 성숙하여 3-4일이 경과한 후에 포자가 방출되어 조도별 차이가 없었다. 일장이 $16 \mathrm{~h}$ 에서는 20-40 $\mu \mathrm{mol}$ photons $\mathrm{m}^{-2} \mathrm{~s}^{-1}$ 에서만 조체의 성숙과 포자방출이 확인되었고, $10 \mu \mathrm{mol}$ photons $\mathrm{m}^{-2} \mathrm{~s}^{-1}$ 에서는 성숙이 일어나지 않았다 (Table 2).

낭과 형성

사분포자에서 생장한 자성배우체는 $15-25^{\circ} \mathrm{C}$ 에서 성숙되었 으며, $25^{\circ} \mathrm{C}$ 에서 배양 22 일 후에 최초로 낭과가 생성되어 2 일 후 과포자를 방출하였다. 이러한 결과는 과포자에서 생장하여 사분포자탁을 형성하기까지 걸리는 시간에 비해 약 7일 정도 빨랐다. 또한 $15^{\circ} \mathrm{C}$ 에서는 배양 29 일에 낭과가 형성되었고 배양 32 일 후에 사분포자가 방출되었으나, $10^{\circ} \mathrm{C}$ 에서 자란 석묵은 배양 45일까지 낭과가 관찰되지 않았다 (Table 2).

일장 및 조도가 자성배우체의 낭과 형성에 미치는 영향을 보면, 낭과의 형성과 포자방출은 $16-24 \mathrm{~h}$ 의 장일 조건에서만 일어났으며, 연속광 $(24 \mathrm{~h})$ 에서는 실험한 모든 조도에서 배양 개시 22일 후에 낭과를 형성하고 3-4일 후에 과포자를 방출함 으로써 조도에 따른 성숙의 차이는 없었으며, $16 \mathrm{~h}$ 의 일장에서

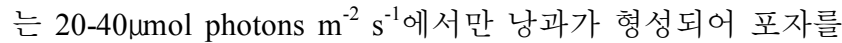
방출하였으나 $10 \mu \mathrm{mol}$ photons $\mathrm{m}^{-2} \mathrm{~s}^{-1}$ 에서는 성숙된 자성배우 체가 관찰되지 않았다 (Table 2).

$$
\text { 고 찰 }
$$

해조류의 생장과 성숙은 다양한 환경조건 (수온, 광, 영양염, 섭식, 경쟁)의 영향을 받는 것으로 알려져 있으나 (Lüning, 1990; Pizaro and Santelices, 1993), 그 중에서 수온과 광이 가장 중요한 제한 요인으로 밝혀져 있다 (Druehl et al., 1987; Vásquez and Vega, 2001). Kain and Norton (1990)은 동일종에서 도 서식지의 수온이 다르면 생장과 성숙과 같은 생물계절적 차이를 보인다고 확인하여 온도의 중요성을 강조하였다. 본 연구에서 보길도 양식 톳에 생육한 석묵은 수온이 $10.52^{\circ} \mathrm{C}$ 인 11 월에 출현하여 수온이 $16.56^{\circ} \mathrm{C}$ 인 6 월에 최대생장을 보이다 가 $18.99^{\circ} \mathrm{C}$ 가 되는 7 월에 소멸되었고 다양한 조도 $(0-160 \mu \mathrm{mol}$ photons $\mathrm{m}^{-2} \mathrm{~s}^{-1}$ )에서 실시된 석묵 배아의 생장실험에서 최대 생장은 $40 \mu \mathrm{mol}$ photons $\mathrm{m}^{-2} \mathrm{~s}^{-1}$ 에서 일어났으며 80 과 $160 \mu \mathrm{mol}$ photons $\mathrm{m}^{-2} \mathrm{~s}^{-1}$ 에서는 생장이 억제되는 것으로 확인되었다 (Yoo, 2009). 따라서 석묵의 여름철 소멸은 수온과 광도가 관련 이 있는 것으로 사료된다. 하지만, 석묵은 갈고리를 이용하여 다른 해조류 (예, 톳과 모자반)에 부착하여 서식하기 때문에 생장하는 동안에 개체의 구분이 불가능 (갈고리 부착부분과 기부 구분이 안됨)하여 톳에 부착된 부분을 기부로 고려한 개체별 갈고리 수, 체장, 무게는 석묵의 생장을 나타내는 변수 (parameter)로 사용하기에는 문제점이 있었다. 한편, 일본의 석묵 야외양성 실험에서는 수온이 $15^{\circ} \mathrm{C}$ 인 7월에 최대 생산량 을 보이다가 $18^{\circ} \mathrm{C}$ 가 되는 8 월 이후에 고사하면서 생물량이 감소되어 (Kirihara et al., 1990), 석묵은 생장과 소멸에 수온이 
밀접한 관련이 있음을 뒷받침하고 있을 뿐만 아니라 석묵은 서식지 수온에 따라 생장 및 소멸시기가 다르다는 것을 보여주 었다.

본 연구에서 석묵의 야외개체군 중 낭과를 가진 과포자체는 11월에서 6월까지 연중 관찰되었으나 성숙은 1월과 4월 사이 에 최대였으며, 사분포자체는 생장이 최대인 5월과 6월에 생식 이 주로 일어난다는 것이 확인되었다. 석묵의 야외개체군에서 생장과 성숙에 대한 계절성은 뚜렷하지 않았지만 암·수배우체 (가을) - 과포자체 (겨울, 초봄) - 사분포자체 (봄, 초여름)로 이 어지는 홍조류의 전형적인 Polysiphonia type의 생활사를 보였 다. 11월 이후에 새롭게 관찰된 석묵의 야외 개체군에서는 출현 1 - 2개월 후인 11월과 12월에 성숙한 사분포자체와 과포자체 가 확인되었다. 석묵의 근연종인 굵은석묵 (C. crassa)의 경우에 는 사분포자체와 과포자체가 연중 관찰되어 석묵에 비해 성숙 에 대한 계절성이 없는 것으로 나타났다 (Boo et al., 1991).

홍조류에서 다양한 종 (Gelidium spp., Chondracanthus chamissoi 등)이 유성생식과 무성생식을 동시에 하는 것으로 알려져 있는데, 착생해조류인 홍조류 석묵은 포자를 이용한 유성생식과 조체의 생물량이 증가하면 갈고리를 타해조류에 부착하여 새로운 조체로 분화하는 무성생식을 병행하는 종이 다 (Notoya, 1979; Kirihara et al., 1990; Yoo, 2009). 해조류의 포자를 이용한 유성생식은 확산 (dispersal)범위를 넓히고 유전 적인 다양성을 확보하는데 도움이 되는 장점이 있고 무성생식 인 영양번식은 빠른 생장과 열악한 환경에서 쉽게 적응할 수 있는 장점이 있다 (Fletcher and Callow, 1992; Santos and Nyman, 1998; Vásquez and Vega, 2001). 본 연구에서 석묵의 개체별 건중량과 갈고리수는 유사한 월별 변화패턴을 보였으 며, 석묵 체장의 월별 변화는 거의 없었는데 이는 착생해조류 인 석묵은 생장하면서 파도에 의한 탈락을 최소화하기 위하여 갈고리로 조체를 고정하는 영양번식을 하였기 때문으로 생각 된다.

석묵은 핵상이 반수체 (haploid)인 배우체와 배수체 (diploid) 인 사분포자체의 생장을 위한 최적 온도 및 광도가 다르게 나타난다 (Notoya, 1979; Kirihara et al., 1990). Notoya (1979)는 일본산 석묵의 최대생장 조건은 사분포자체가 $20^{\circ} \mathrm{C}$ 의 160 $\mu \mathrm{mol}$ photons $\mathrm{m}^{-2} \mathrm{~s}^{-1}$, 사분포자에서 유래한 배우체가 $20^{\circ} \mathrm{C}$ 의 $40 \mu \mathrm{mol}$ photons $\mathrm{m}^{-2} \mathrm{~s}^{-1}$ 로써 온도는 동일하지만 조도가 다르게 나타났고 사분포자체가 배우체에 비해 빠른 생장을 보인다고 하였다. Kirihara et al. (1990)은 사분포자체 $\left(15^{\circ} \mathrm{C}\right)$ 와 자성배우 체 $\left(25^{\circ} \mathrm{C}\right)$ 의 최적 생장 수온이 다르지만, 일장은 $14 \mathrm{~h}$ 로 동일하 다고 기록하였으며, 자·웅 배우체를 구분하여 배양하면 자성배 우체가 사분포자체에 비해 빠른 생장을 보인다고 하였다. 본 연구에서 석묵은 일장이 길수록, 특히 $24 \mathrm{~h}$ 의 연속광에서 빠른 생장을 보여 장일조건에서 좋은 생장을 보인다는 Kirihara et al. (1990)의 결과와 유사하였으며, 사분포자체가 배우체에 비 해 약간 빠른 생장을 보였다. 본 연구에서 석묵의 사분포자체 배아의 최대생장은 $25^{\circ} \mathrm{C}$ 였고, Notoya (1979)는 $20^{\circ} \mathrm{C}$, Kirihara et al. (1990)은 $15^{\circ} \mathrm{C}$ 로 기록하여 개체군별로 차이를 보였으나, 배우체는 $20^{\circ} \mathrm{C}$ 로서 다른 연구자와 매우 유사하였다. 이처럼,
한국산과 일본산 석묵의 수온과 광에 대한 생리적, 그리고 생활사 단계 (배우체, 사분포자체)별 생장의 차이는 서식환경, 성숙의 발생유무 (Kirihara et al., 1990)의 차이에서 기인한 것으로 사료된다. 또한, 석묵 배우체 배아의 생장률은 $35 \mathrm{psu}$ 에 서 $0.26 \mathrm{day}^{-1}$ 로서 $15 \mathrm{psu}$ 의 $0.20 \mathrm{day}^{-1}$ 에 비해 높은 것으로 확인 되어 유용 해조류인 석묵은 배우체에 비해 생장이 빠른 사분포 자체를 양식대상으로 하고 염분농도가 $35 \mathrm{psu}$ 인 외해에서 수 행되어야 할 것으로 판단된다. 석묵의 자연개체군이 부유물질 이 적어 투명한 해역 그리고 물의 흐름이 있는 곳에서 발견되 는 것으로 보아 해수의 영양염과 투명도 역시 석묵 양식에 고려되어야 할 환경요인으로써 차후에 연구가 수행되어야 할 것으로 생각된다.

해조류의 생장과 성숙의 조절요인이 일장 혹은 개체에 도달 하는 총광량과 관련이 있는지를 밝히기 위해서는 일장과 조도 로 일평균조도 (MDI, mean daily irradiance)를 계산하여 확인 하여야 한다 (Chapman and Burrows, 1970; Han and Kain, 1996). 본 연구에서 석묵은 $\mathrm{MDI}$ 의 값이 $20 \mu \mathrm{mol}$ photons $\mathrm{m}^{-2} \mathrm{~s}^{-1}\left(24 \mathrm{~h}, 20 \mu \mathrm{mol}\right.$ photons $\mathrm{m}^{-2} \mathrm{~s}^{-1}$ 과 $12 \mathrm{~h}, 40 \mu \mathrm{mol}$ photons $\left.\mathrm{m}^{-2} \mathrm{~s}^{-1}\right)$ 과 $10 \mu \mathrm{mol}$ photons $\mathrm{m}^{-2} \mathrm{~s}^{-1}\left(24 \mathrm{~h}, 10 \mu \mathrm{mol}\right.$ photons $\mathrm{m}^{-2}$ $\mathrm{s}^{-1}$ 과 $12 \mathrm{~h}, 20 \mu \mathrm{mol}$ photons $\mathrm{m}^{-2} \mathrm{~s}^{-1}$ )로 동일할 때 과포자체 배아와 사분포자체 배아는 모두 장일조건에서 빠른 생장을 보였으며, 성숙도 장일조건인 $16 \mathrm{~h}\left(20,40 \mu \mathrm{mol}\right.$ photons $\mathrm{m}^{-2}$ $\left.\mathrm{s}^{-1}\right)$ 와 $24 \mathrm{~h}\left(10,20,40 \mu \mathrm{mol}\right.$ photons $\left.\mathrm{m}^{-2} \mathrm{~s}^{-1}\right)$ 에서만 일어남으로 써 석묵의 생장 및 성숙은 $\mathrm{MDI}$ 보다 일장의 영향을 주로 받는 것으로 판단된다.

포자방출의 조건 파악은 유용종의 종묘확보를 위해서 꼭 필요한 연구분야로서 잘 알려져 있으며, 온도, 조도 및 삼투충 격과 같은 다양한 방법으로 포자 방출실험을 수행하였다 (Friedlander and Dawes, 1984; Santelices 1990; GuzmánUrióstegui and Robledo, 1999). 석묵 과포자체의 낭과에서 포 자방출을 유도한 결과, 장일조건에서 그리고 $15-20^{\circ} \mathrm{C}$ 에서 포자방출량이 최대였다. 일장의 증가에 따른 포자방출의 증 가는 Acrochaetium spp. (White and Boney, 1969), Gelidium pusillum, Pterocladia heteroplatos (Umamaheswara Rao and Kaliaperumal, 1983)에서도 확인되었다. 본 연구에서 석묵 과 포자의 최대 방출조건은 $15-20^{\circ} \mathrm{C}$ 로 우리나라 봄 - 초여름의 수온과 유사하고, 실험한 조도 중에서 가장 높은 $40 \mu \mathrm{mol}$ photons $\mathrm{m}^{-2} \mathrm{~s}^{-1}$ 과 장일조건에서 방출량이 많은 것은 자연상태 에서 석묵이 많은 광을 확보하기 위하여 모자반류와 같은 다 른 해조류에 착생해조류로 존재하는 생태학적 이유를 부분적 으로 해석할 수 있을 것 같다.

결론적으로 유용해조류인 석묵을 대량으로 해면양식하기 위해서는 육안적 구별이 용이한 낭과를 가진 과포자체를 채 집하여 과포자를 대량으로 방출 및 채묘하여 빠른 생장을 보 이는 사분포자체를 양식해야한다. 즉 양식방법으로는 석묵의 야외개체군에서 성숙한 낭과가 많이 관찰되는 겨울 (11-1월) 에 채묘하여 $1-5$ 월까지 야외 양성하여 조체의 체장과 건중량 이 최대인 6월에 수확하는 것이 좋을 것으로 판단된다. 또한, 석묵이 저염분에 비해 고염분에서 좋은 생장을 보인 것으로 
보아서 담수의 영향이 적은 외해에서 양식이 이루어져야 할 것으로 사료된다.

사 사
본 연구는 농림수산식품부 수산기술개발사업의 지원에 의 해 이루어졌으며, 연구수행에 도움을 주신 원광대학교 해양생 물학 실험실원, 전라남도 수산기술사업소 장흥지소와 해남지 소의 선생님들께 감사드립니다.

\section{참고문헌}

Boo SM. 1991. A Biosystematic Study on the Genus Campylaephora J. Agardh Rhodophyta. Ministry of Science and Technology Report, 1-51.

Boo SM, Fredriksen S, Rueness J and Lee IK. 1991. Field and culture studies on the life history of Campylaephora crassa (Okamura) Nakamura (Ceramiaceae, Rhodophyta). Bot Mar 34, 437-45.

Chapman ARO and Burrows EM. 1970. Experimental investigations into the controlling effects of light conditions on the development and growth of Desmarestia aculeata (L.) Lamour. Phycol 9, 103108.

Choi HG, Kim YS, Kim JH, Lee SJ, Park EJ, Ryu J and Nam KW. 2006. Effects of temperature and salinity on the growth of Gracilaria verrucosa and G. chorda, with the potential for mariculture in Korea. J Appl Phycol 18, 269-277.

Destombe C, Godin J, Nocher M, Richerd S and Valero M. 1993. Differences in response between haploid and diploid isomorphic phases of Gracilaria verrucosa (Rhodophyta: Gigartinales) exposed to artificial environmental conditions. Hydrobiologia 260/261, 131-137.

Do JR, Kim EM, Koo GK and Jo KS. 1997. Dietary fiber contents of marine algae and extraction condition of the fiber. J Kor Fish Soc 30, 291-296.

Druehl LD, Cabot EL and Lloyd KE. 1987. Seasonal growth of Laminaria groenlandica as a function of plant age. Can J Bot 65, 1599-1604.

Fletcher RL and Callow ME. 1992. The settlement, attachment and establishment of marine algal spores. Br Phycol J 27, 303-329.

Fonck E, Venegas M, Tala F and Edding M. 1998. Artificial induction of sporulation in Lessonia (Phaeophyta, Laminariales). J Appl Phycol 10, 399-403.

Friedlander M and Dawes CJ. 1984. Studies on spore release and sporeling growth from carpospores of Gracilaria foliifera (Førsskäl) Børgesen var. angustissima (Harvey) Taylor. I. Growth responses.
Aquatic Bot 19, 221-232.

González J and Meneses I. 1996. Differences in the early stages of development of gametophytes and tetrasporophytes of Chondracanthus chamissoi (CAg) Kützing from Puerto. Aldea, Northern Chile. Aquaculture 143, 91-107.

Guzmán-Urióstegui A and Robledo D. 1999. Factors affecting sporulation of Gracilaria cornea (Gracilariales, Rhodophyta) carposporophytes from Yucatan, Mexico. Hydrobiologia, 398/399, 285-90.

Han T and Kain JM. 1996. Effect of photon irradiance and photoperiod on young sporophytes of four species of the Laminariales. Eur J Phycol 31, 233-240.

Kain JM and Norton TA. 1990. Marine Ecology. In: Biology of the Red Algae. Cole, K.M. and R.G. Sheath, eds. Cambridge University Press, Cambridge, U.K., 377-422.

Kang JW. 1968. Illustrated Encyclopedia of Fauna and Flora of Korea. Vol. 8. Marine algae. Sam Hwa Press, Seoul, Korea, 1-465.

Kirihara S, Notoya M and Aruga Y. 1990. Cultivation of Campylaephora hypnaeoides J. Agardh (Ceramiales, Rhodophyta). Jpn J Phycol 38, 377-382.

Lüning K. 1990. Seaweeds. Their Environment, Biogeography, and Ecophysiology. Wiley, New York, U.S.A., 1-527.

Matsui T. 1969. Studies on the liberation and germination of spores in Gloiopeltis tenax (Turn.) J. Ag. and G. furcata et. Rupr. J Shimonoseki Univ Fish 17, 185-231.

NFRDI. 2007. Korea Oceanographic Data Center. Retrieved from http://kodc.nfrdi.re.kr

Notoya M. 1979. Life history of Campylaephora hypnaeoides J. Agardh (Ceramiaceae, Rhodophyta) in culture and environmental regulation of reproduction. Jpn J Phycol 27, 201-204.

Pizarro A and Santelices B. 1993. Environmental variation and large scale Gracilaria production. Hydrobiologia 260/261, 357-363.

Provasoli L. 1968. Media and prospects for the cultivation of marine algae. In: Cultures and Collections of Algae. Watanabe, A. and A. Hattorc, eds. Proceedings of a United States-Japan Conference held at Hakone. 1966. 63-75.

Rueness $\mathrm{J}$ and Tananger T. 1984. Growth in culture of four red algae from Norway with potential for mariculture. Hydrobiologia 116, 303-307.

Santelices B. 1990. Patterns of reproduction, dispersal and recruitment in seaweeds. Oceanogr Mar Biol Ann Rev 28, 177-276. 
Santos R and Nyman M. 1998. Population modelling of Gelidium sesquipedale (Rhodophyta, Gelidiales). J Appl Phycol 10, 261-272.

Subba Rangaiah G. 1985. Influence of temperature on diurnal periodicities of tetraspores of some members of Gigartinales (Rhodophyta). Seaweed Res Utiln 8, 23-27.

Umamaheswara Rao M and Kaliaperumal N. 1983. Effects of environmental factors on the liberation of spores from some red algae of Visakhapatnam coast. J Exp Mar Biol Ecol 70, 45-53.

Vásquez JA and Vega JMA. 2001. Chondracanthus chamissoi (Rhodophyta, Gigartinales) in northern Chile: ecological aspects for management of wild populations. J Appl Phycol 13, 267-277.

White EB and Boney AD. 1969. Experiments with some endophytic and endozoic Acrochaetium species. J Exp Mar Biol Ecol 3, 246-274.

Yoo HI. 2009. Cultivation trial of Campylaephora hypnaeoides in laboratory and field. Master Degree Thesis. Wonkwang University, Iksan, Korea.

Yoo HI, Kim JH and Choi HG. 2010. Effects of sediment (silt), water movement, and light intensity on the survival and growth of sporelings of epiphytic Campylaephora hypnaeoides. Kor J Fish Aquat Sci 43, 239-245.

$\begin{array}{rrr}\text { 2010년 } & \text { 4월 22일 접수 } \\ \text { 2011년 } & \text { 4월 7일 수정 } \\ \text { 2011년 } & \text { 6월 14일 수리 }\end{array}$

2011년 6월 14일 수리 